\title{
Contribution of Microbe-Mediated Processes in Nitrogen Cycle to Attain Environmental Equilibrium
}

\author{
Humera Quadriya, Mohammed Imran Mir, K. Surekha, \\ S. Gopalkrishnan, M. Yahya Khan, Sushil K. Sharma, and \\ Hameeda Bee
}

\begin{abstract}
Nitrogen $(\mathrm{N})$, the most important element, is required by all living organisms for the synthesis of complex organic molecules like amino acids, proteins, lipids etc. Nitrogen cycle is considered to be the most complex yet arguably important cycle next to carbon cycle. Nitrogen cycle includes oxic and anoxic reactions like organic $\mathrm{N}$ mineralization, ammonia assimilation, nitrification denitrification, anaerobic ammonium oxidation (anammox), dissimilatory nitrate reduction to ammonium (DNRA), comammox, codenitrification etc. Nitrogen cycling is one of the most crucial processes required for the recycling of essential chemical requirements on the planet. Soil microorganisms not only improve N-cycle balance but also pave the way for sustainable agricultural practices, leading to improved soil properties and crop productivity as most plants are opportunistic in the uptake of soluble or available forms of $\mathrm{N}$ from soil. Microbial $\mathrm{N}$ transformations are influenced by plants to improve their nutrition and vice versa. Diverse microorganisms, versatile metabolic activities, and varied biotic
\end{abstract}

H. Quadriya $\cdot$ H. Bee $(\square)$

Department of Microbiology, Osmania University, Hyderabad, Telangana, India

M. I. Mir

Department of Botany, Osmania University, Hyderabad, Telangana, India

K. Surekha

ICAR-Indian Institute of Rice Research, Rajendranagar, Hyderabad, Telangana, India

S. Gopalkrishnan

ICRISAT-International Crops Research Institute for the Semi-Arid Tropics, Hyderabad, Telangana, India

M. Yahya Khan

Kalam Biotech Private Limited, Hyderabad, Telangana, India

S. K. Sharma

ICAR-National Institute of Biotic Stress Management (ICAR-NIBSM), Raipur, Chhattisgarh, India

S. K. Sharma et al. (eds.), Rhizosphere Microbes, Microorganisms for Sustainability

23, https://doi.org/10.1007/978-981-15-9154-9_13 
and abiotic conditions may result in the shift in the equilibrium state of different $\mathrm{N}$-cycling processes. This chapter is an overview of the mechanisms and genes involved in the diverse microorganisms associated in the operation of nitrogen cycle and the roles of such microorganisms in different agroecosystems.

\section{Keywords}

Nitrogen cycle $\cdot \mathrm{N}$-linked microbial processes $\cdot$ Environmental factors · Agroecosystems

\subsection{Introduction}

Global nitrogen cycle deals with the movement of various forms of N, either reactive or unavailable across various reservoirs and ecosystems. Nitrogen availability can be predicted by the presence of diverse and metabolically versatile microorganisms. Reactive nitrogen $(\mathrm{Nr})$ species include $\mathrm{NO}^{-3}, \mathrm{NO}^{-2}, \mathrm{NH}_{3}, \mathrm{NH}^{4+}, \mathrm{NO}_{\mathrm{x}}, \mathrm{N}_{2} \mathrm{O}$, urea, amides, etc. These nitrogen transformation result into production of available forms of nitrogen leading to shift in nitrogen cycle equilibrium. The associated reactions either reduce or intensify global environmental change and produce/consume greenhouse gases. Microorganisms play a vital role in maintaining geochemical $\mathrm{N}$ cycle across the globe. These microbial processes namely nitrogen fixation, nitrification, ammonification, denitrification, etc. are mediated by Cyanobacteria, Azotobacter, Nitrosomonas, Nitrobacter, Nitrococcus, Rhizobium, etc. Assimilation of nitrates and ammonium ions are mediated through conversion into complex molecules, like amino acids, proteins, etc. in living beings. While some plants provide amino acids and/or nutrients to bacteroids, these bacteria in turn fix nitrogen and provide amino acids back to plants through symbiotic relationship. Further, conversion of nitrate to ammonium is mediated by microorganisms through the process of dissimilatory nitrate reduction. Anammox is anaerobic ammonium oxidation, wherein nitrite and ammonium combine to form nitrogen. The key genes steering microbial $\mathrm{N}$ cycle include nif (nifHDK); amoA; narG; nirS/K; and nosZ genes (David et al. 2014).

Agroecosystem is considered to be the major ecosystem in India, with highest quantum of $\mathrm{N}$ fertilizer utilization and loss as well. This excess nitrogen fertilization is a threat to human, animal, and environment. According to Rockstrom et al. (2009), three of the nine interlinked planetary boundaries (rate of biodiversity loss (terrestrial, marine), interference with the $\mathrm{N}$ cycle, and climate change) have been crossed as a result of industrialized form of agriculture and anthropogenic activities, which if not stopped or rectified can lead to disastrous consequences or irreversible environmental changes. Interference with $\mathrm{N}$ cycle is due to excess fertilizer application to enhance cereal production, followed by energy, industrial, and wastewater management (Abrol et al. 2017). According to Pathak (2015), greenhouse gas (GHG) emissions increased 75\% from 1970 to 2010, of which $\mathrm{N}_{2} \mathrm{O}$ emissions doubled, and $\mathrm{N}_{2} \mathrm{O}$ was the second largest emitted GHG after $\mathrm{CH}_{4}$. In addition to this, $\mathrm{Nr}$ (reactive nitrogen) emissions are due to puddled rice; horticultural production 
systems; burning of crop residues, livestock and poultry etc. which lead to nitrate leaching and groundwater pollution (Abdullah et al. 2017). Due to this, we are witnessing nitrogen-deficient food and food products (Abrol et al. 2017). In this chapter, we will discuss the role of microorganisms, the genes involved in $\mathrm{N}$ cycle, microbial diversity in different ecosystems, and the role of microbes in maintaining $\mathrm{N}$ equilibrium.

\subsection{Nitrogen Cycle: The Role of Microorganisms}

Nitrogen is important for muscle movement and other body functions, an essential component of protein, and an integral part of protein synthesis, photosynthesis, and other critical biological processes. It is predicted that $\mathrm{N}$ fixed by human activities would be greater than N fixed by microbial processes (Fowler et al. 2013; David et al. 2014; Silvia and Brendan 2016; Ramiro and Silvia 2018).

$\mathrm{N}$ cycle is the most important cycle after carbon cycle as both nitrogen and carbon (C) are required mainly for the synthesis of essential biomolecules. Nitrogen cycle includes organic $\mathrm{N}$ mineralization, ammonia assimilation, bacterial and archaeal nitrification (autotrophic and heterotrophic), comammox, anammox, dissimilatory nitrate reduction, and denitrification and codenitrification. The major genes associated with the biogeochemical cycle of nitrogen are as follows: (1) nif for nitrogen fixation; (2) $a m o A$ and $a m o B$ for archaeal and bacterial ammonification/ ammonia oxidation; (3) chi A for mineralization; (4) nar and nap for nitrate reduction; (5) nirS and nirK for nitrite reduction; (6) norB for nitric oxide reduction; (7) nosZ for nitrous oxide reduction; (8) nrfA for DNRA (dissimilatory nitrate reduction to ammonium); (9) hzo, $h h$ and $h z s$ for anammox; (10) pmoA/amoA, norB and hao for comammox and (11) nap, nor, nir and nos together in different steps of denitrification (Fig. 13.1). Microorganisms respond differently to various biotic and abiotic factors and result in a shift in the equilibrium state of $\mathrm{N}$ cycle (Shoun et al. 2012; Lisa and Martin 2016; Olivia et al. 2017; Florence et al. 2018).

\subsubsection{Nitrogen Fixation}

Almost $80 \%$ of Earth's atmosphere contains nitrogen gas, but the availability of nitrogen is still limited. Nitrogen fixation becomes accelerated/limited based on the presence/absence of factors like iron $(\mathrm{Fe})$, molybdenum $(\mathrm{Mo})$, phosphorus $(\mathrm{P})$, and cobalt (Co) (Dilworth et al. 1978; Howarth et al. 1988; Vitousek 1999). Net biologically available nitrogen is determined by balancing between denitrification and nitrogen fixation. Nitrogen status in the environment is controlled as a result of interactions among $\mathrm{N}_{2}$ fixation and other biogeochemical processes of cycle. The process of getting biologically available forms from dinitrogen is called nitrogen fixation. Dinitrogen is chemically inert due to triple bond and requires a large amount of energy, i.e., eight electrons and 16 adenosine triphosphate (ATP) molecules, to convert a dinitrogen molecule into ammonia. On the other side, 


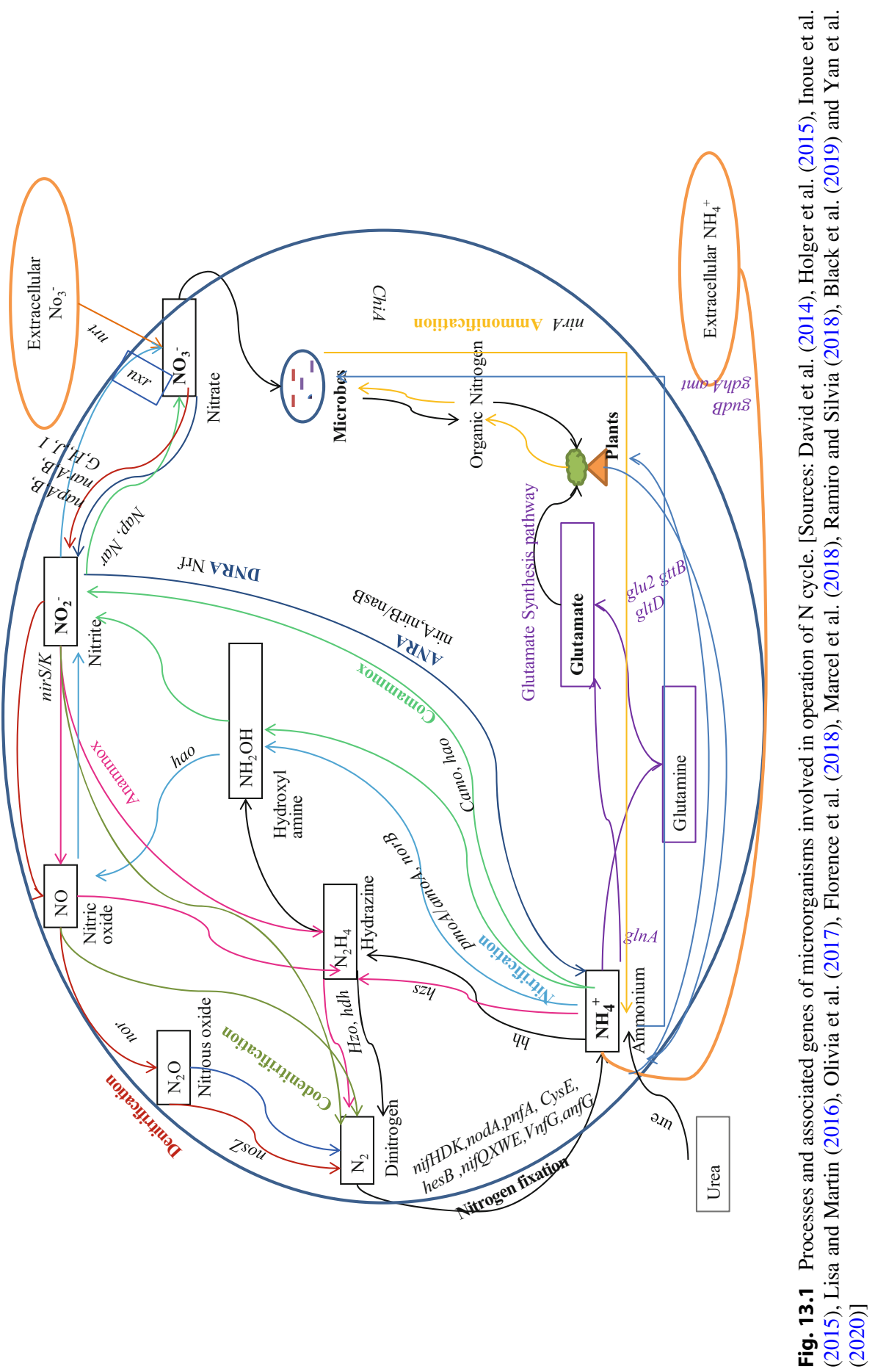


environmental lighting also adds to $\mathrm{N}$ fixation naturally. Industrial nitrogen fixation (Haber-Bosch method) is also carried out, but it is not that much economic.

Nitrogen fixers may be symbiotic and asymbiotc (free-living). Symbiotic fixers are divided into (1) aerobic and anaerobic and (2) phototrophic and chemotrophic, based on their oxygen requirement and light or chemical requirement for fixation, respectively. In order to maintain symbiosis, specific mechanisms and enzyme complexes are required. Though prokaryotes have diverse physiological processes among $\mathrm{N}$ fixers, they contain similar enzyme complex. One of the enzymes is nitrogenase, which is oxygen sensitive and reduces dinitrogen to ammonia. With time, $\mathrm{N}$ fixers have gradually developed ways to protect nitrogenase from oxygen, like heterocysts in Cyanobacteria, while some others carry out nitrogen fixation during the night, when oxygen is not synthesized due to its dormant photosystem (David et al. 2014; Danovaro et al. 2017; Dilfuza 2018).

$$
\begin{aligned}
\mathrm{N}_{2}+8 \mathrm{H}^{+}+8 \mathrm{e}^{-} & \rightarrow 2 \mathrm{NH}_{3}+\mathrm{H}_{2} \uparrow \text { and 16ATP } \\
& \rightarrow 16 \mathrm{ADP}+16 \mathrm{Pi}(\text { with Mo }- \text { nitrogenase) } \\
\mathrm{N}_{2}+14 \mathrm{H}^{+}+12 \mathrm{e}^{-} & \rightarrow 2 \mathrm{NH}_{4}^{+}+3 \mathrm{H}_{2} \uparrow \text { and } 40 \mathrm{ATP} \\
& \rightarrow 40 \mathrm{ADP}+40 \mathrm{Pi}(\text { with } \mathrm{V}-\text { nitrogenase) }
\end{aligned}
$$

Nitrogenase enzyme complex is comprised of two multisubunits metalloprotein. In conventional nitrogenases, Fe-S subunits are bridged by Mo, i.e., Mo-nitrogenase (Fe-Mo-S), whereas alternative nitrogenases contain either $\mathrm{V}$ or $\mathrm{Fe}$, i.e., $\mathrm{V}$-nitrogenase (Fe-V-S) or Fe-only nitrogenase (Fe-Fe-S). All the three types of enzymes are similar in sequences and structural and functional properties but varied in metal cofactor. Azotobacter vinelandii contains all the three types of enzymes, while Trichodesmium spp. have Mo-nitrogenase and V-nitrogenase, which is rarely present. The gene clusters for nitrogenase enzymes based on the above three metal requirements are, respectively, nif and non-nif; vnf or anf, comprising major clusters of genes nifHDK and cys, mod; and $v n f H D G K$ or anfHDGK, along with minor clusters $(Q B X W O)$. As depicted in the above reactions, it is clear that Mo-nitrogenase requires comparatively less electron flux, less energy/ATP, and less nitrogen pressure, thereby resulting in 1:1 N-fixed: $\mathrm{H}_{2}$ evolved ratio, while the other two have increased values up to 7:1 to 9:1 N-fixed: $\mathrm{H}_{2}$ evolved ratio (Florence et al. 2018; Marcel et al. 2018).

$\mathrm{N}$ fixation is a fairly expensive process metabolically, where approximately $20 \mathrm{~kb}$ DNA (genes) encodes proteins required for $\mathrm{N}$ fixation (Chen et al. 1998; Kim et al. 1999; Hoover 2000). Factors regulating N fixation can be checked by transcribing nifHDK operon, which is not constitutively expressed. A strong reductant, iron protein, "Ferredoxin," carries electron and reduces catalytic components during nitrogen fixation. This reduction and electron transfer need iron and catalytic protein to dissociate and reassociate (Marcel et al. 2018).

According to Graham et al. (1988), rhizobia behave as free-living organism when present in soil and as a symbiont in root-nodule. Various nutrients affect their growth in the root like calcium $(\mathrm{Ca})$ for multiplication, cobalt $(\mathrm{Co})$ for nodule initiation, and 
boron (B) and iron ( $\mathrm{Fe}$ ) for nodule development. Cobalt accelerates nitrogen fixation, participates in "cobamide" coenzyme catalyst formation, and is the center of cyanocobalamin. There are enzymes like methylmalonyl-coenzyme A mutase and methionine synthase that are dependent on cobalamin, especially in rhizobia, which would affect the concentration of leghemoglobin. Cobalt (Co) acts as a cofactor for cobalamin during $\mathrm{N}$ fixation and nodule growth. It has a role in the activity and population of nitrogen fixers like Azotobacter and Cyanobacteria.

The presence of Co only or Mo when applied along with Co has shown an increase in nodule formation, nutrient content, and yield and growth in legumes, and studies also revealed lesser use of fertilizer dose than recommended dose. There is antagonistic relation between Fe and Co (Dilworth et al. 1978; Graham et al. 1988; Nadia 2012; Weria et al. 2013; Campo et al. 2000).

\subsubsection{Nitrification}

Nitrification is an oxidation process that converts ammonium into nitrate via nitrite. It involves two pathways: autotrophic nitrification and heterotrophic nitrification. Factors contributing to both include the nature and availability of substrates in soils. In addition to this, acidic soils inhibit the activity of autotrophic nitrifiers while favoring heterotrophic nitrifiers. In heterotrophic nitrification, oxidation of ammonia is not coupled to energy conservation and the enzymes regulating both pathways are different.

\subsubsection{Autotrophic Nitrification}

\section{Aerobic Nitrification}

Nitrification is a process wherein ammonia in converted in nitrate via nitrite. A major percentage of nitrification is carried out by prokaryotes under aerobic conditions. Hydroxylamine is the intermediate form in the first step, where aerobic ammonia oxidizers convert ammonium to nitrite, generating a little amount of energy that utilizes two different enzymes-ammonia monooxygenase (AMO) and hydroxylamine oxidoreductase (HAO). It is carried out not only by a few bacteria but majorly by archaea (David et al. 2014). In the next step, oxidation of nitrite to nitrate is carried out by nitrite-oxidizing bacteria; some genera involved are Nitrospira, Nitrobacter, and Nitrospina. These ammonium and nitrite oxidizers are autotrophic, slow growers that synthesize organic carbon but utilize ammonia as their energy source instead of light. Nitrospira moscoviensis respires nitrate while utilizing hydrogen in aerobic and organic acids in an anaerobic environment. Ammonia and nitrite oxidizers help maintain environmental balance by the removal of potentially toxic ammonia level.

Aerobic nitrite oxidation conserves energy, while anaerobic process does not. Mostly, aerobic and anaerobic nitrite oxidation is carried out by NXR (nitrate oxidoreductase), with few exceptions like Thiocapsa sp. KS1 and Rhodopseudomonas sp. LQ17 (Marcel et al. 2018). 


$$
\begin{aligned}
& \text { 1) } \underset{\text { Ammonia }}{\mathrm{NH}_{3}}+\underset{\text { Oxygen }}{\mathrm{O}_{2}}+2 \mathrm{e}^{-} \rightarrow \underset{\text { Hydroxyamine }}{\mathrm{NH}_{2} \mathrm{OH}+\mathrm{H}_{2} \mathrm{O}} \rightarrow \mathrm{NO}_{2^{-}}+\underset{\text { Nitrite }}{5 \mathrm{H}^{+}}+4 \mathrm{e}^{-} \\
& \text {2) } 2 \underset{\text { Nitrite }}{\mathrm{NO}_{2^{-}}}+\underset{\text { Oxygen }}{\mathrm{O}_{2}} \rightarrow 2 \underset{\text { Nitrate }}{\mathrm{NO}_{3^{-}}}
\end{aligned}
$$

\section{Comammox}

Comammox can be defined as complete microbial oxidation of ammonium/ammonia to nitrate in one step. Chemolithotrophic microorganisms in second cohort utilize nitrite as reductant and are confined to Cohort II of lineage II of Nitrospira genus of Proteobacteria class in phylum Nitrospirae and third cohorts utilize ammonia as reductant for cellular growth and Cohort III have high affinity for ammonia, lower growth rate, and higher growth yield than typical ammonia oxidizers. A few examples include Candidatus Nitrospira nitrosa, Candidatus Nitrospira nitrificans, and Nitrospira inopinata with new gene camoA, which is similar to amoA; additionally, new enzymes AMO and hydroxylamine oxidoreductase (HAO) are similar to typical enzymes of ammonia-oxidizing bacteria (AOB). These organisms lack enzymes for assimilatory nitrite reduction and instead are able to take up ammonia/urea-based ammonia via urease-encoding genes (Holger et al. 2015; Kessel et al. 2015; Lisa and Martin 2016; Hu and He 2017).

$$
\begin{gathered}
\underset{\text { Ammonium/Ammonia }}{\mathrm{NH}_{4^{+}} / \mathrm{NH}_{3}} \rightarrow \underset{\text { Hydroxylamine }}{\mathrm{NH}_{2} \mathrm{OH}} \rightarrow \underset{\text { Nitrite }}{\mathrm{NO}_{2^{-}}} \rightarrow \underset{\text { Nitrate }}{\mathrm{NO}_{3^{-}}} \\
\underset{\text { Ammonium }}{\mathrm{NH}_{4^{+}}} \rightarrow \underset{\text { Nitrite }}{\mathrm{NO}_{2^{-}}} \rightarrow \underset{\text { Nitrate }}{\mathrm{NO}_{3^{-}}}
\end{gathered}
$$

\section{Anammox}

In contrast to nitrification, anammox (anaerobic ammonium oxidation) takes place in an oxygen-limited environment like the rhizosphere of rice and oceans. Strous et al. (1999) discovered that ammonia oxidation is even carried out in anoxic conditions by prokaryotes. Candidatus (Ca) Brocadia anammoxidans is the first anammoxperforming bacterium reported, and it uses nitrite as electron acceptor to oxidize ammonia and synthesize nitrogen. Haem4 is the catalytic center of octaheme hydroxylamine oxidoreductase (HAO) in anaerobic ammonium-oxidizing bacteria, Kuenenia stuttgartiensis (Marcel et al. 2018). Anaerobic ammonium oxidation or anammox take up both ammonium and nitrite to form dinitrogen from nitric oxide and/or hydrazine as intermediate form/s; hence, it is also referred to as nitrificationdenitrification process catalyzed by hydrazine synthase (HZS). This process is carried out in the "anammoxosome," a specific membrane-bound organelle containing hydrazine dehydrogenase $(\mathrm{HDH})$, HZS, NIR, hydroxylamine oxidase (HOX), and NOR enzymes in Kuenenia and members of Brocadiaceae of Planctomycetales. The gene hzsA (hydrazine synthase) is considered as genetic markers for anammox (Harhangi et al. 2012). It is a major nitrogen removal process, may be nitrite or ammonium without the production of $\mathrm{N}_{2} \mathrm{O}$, and hence ecologically 
beneficial and applied industrially for wastewater treatment (Lisa and Martin 2016; Marcel et al. 2018).

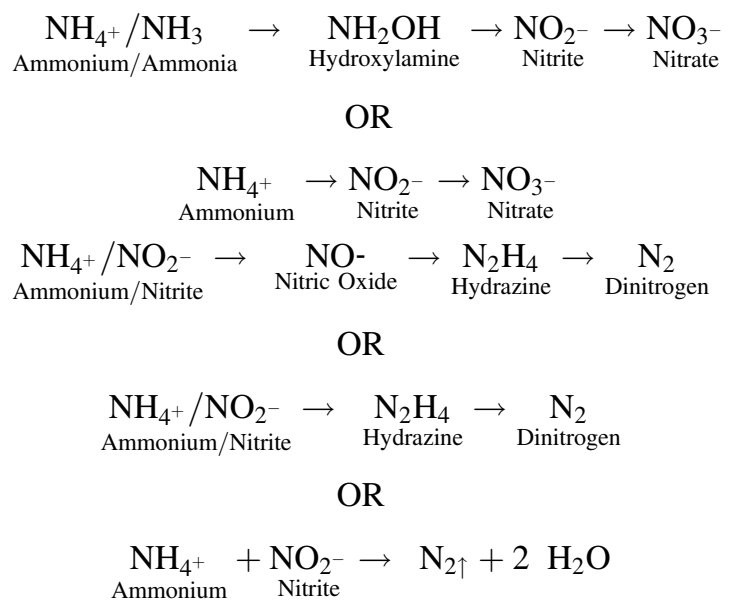

According to David et al. (2014), bacterial and archaeal nitrifiers are significantly different. Crenarchaeota oxidizes ammonia by nitroxyl (HNO) as it lacks HAO. Archaea here requires less oxygen and is useful in anoxic zones of soil. Bacterial ammonia oxidation is restricted to $\beta$ - and $\gamma$ - Proteobacteria. Methanotrophs are capable of utilizing ammonia in scarcity of methane to produce hydroxylamine by methane monooxygenase (MMO). HAO is an octahaem protein that involves endergonic reaction for the oxidation of hydroxylamine to nitric oxide, and then it is converted to nitrite (Marcel et al. 2018).

Autotrophic nitrification contributes to proportional relatedness with increased soil $\mathrm{pH}$ and raised $\mathrm{N}_{2} \mathrm{O}$ level and is inversely related to denitrification, soil $\mathrm{pH}$, and $\mathrm{N}_{2} \mathrm{O}$ emission (Zhang et al. 2015). Low $\mathrm{pH}$ and low ammonia are assumed to hinder ammonia oxidation by chemolithoautotrophs, but this was proved reverse by the isolation of Candidatus Nitrosotalea devanaterra. Soils with sandy and silty clay texture witness abundant Thaumarchaeota than bacteria. Ammonia is produced from the hydrolysis of organic $\mathrm{N}$ compounds like urea and cyanate by Nitrosospira sp., Nitrososphaera viennensis and Nitrososphaera gargensis with ureases and cyanase, respectively (Marcel et al. 2018).

Soils fertilized by manure or compost which receive ammonical substrate represents increase in the ratio of gross nitrification rate to nitrification potential (GNR:NP). Agricultural soils are acidified due to higher rates of nitrification and leaching of nitrates. Population abundance and ecotype of ammonia and nitrite oxidizers more or less regulate nitrification rate in the presence of higher substrate concentration. There are examples, such as one from Utah agriculture soils, where ammonia-oxidizing archaea (AOA) represented lower $\mathrm{V}_{\max }$ at lower substrate concentration. During the first few weeks of fertilization, ammonia-oxidizing bacteria (AOB) mediated net and gross nitrification rates as ammonium got 
depleted and AOA overcame AOB. Another example can be of Oregon soils, where lower ammonium concentration saturates nitrification via AOA. Zhu et al. (2018) revealed that bacteriovorous nematodes significantly reduced AOB while increasing AOA abundance (Norton and Yang, 2019). In a few plants, root exudates synthesize inhibitors that hinder nitrification activities (Subbarao et al. 2013, 2015).

\subsubsection{Urea Hydrolysis}

Nitrification include ammonia-oxidizing microbes (AOM) and nitrite-oxidizing bacteria (NOB) of genera Nitrospira and Nitrospina those convert ammonia to nitrite followed by nitrate. It has been recently reported that the same AOM also converts urea into ammonia and bicarbonate using own produced urease enzyme.

Urea is first hydrolyzed to ammonia and carbamate, which is quickly converted into second ammonia molecule and a bicarbonate by urease-positive AOM. This ammonia is then converted to nitrite by urease-negative AOM or NOB, thereby reducing the competition for free nitrite availability. The genus Nitrospira contains genomically and functionally variable organisms, i.e., AOM (bacteria and archaea) and NOB like urease-positive Nitrospira moscoviensis and urease-negative $N$. defluvii and N. europaea coexisting in natural soils and activated sludge. Based on ammonia availability, AOM and NOB outcompete each other or sometimes behave mutually symbiotic. Therefore, soils should be fertilized in an efficient way that would not alter much the community or composition of the microorganisms present (Kocha et al. 2015).

$$
\underset{\text { Urea }}{\mathrm{NH}_{2} \mathrm{CoNH}_{2}} \rightarrow \underset{\text { Ammonia }}{\mathrm{NH}_{3}}+\underset{\text { Carbanate }}{\mathrm{COONH}_{2}} \rightarrow \underset{\text { Ammonia }}{2 \mathrm{NH}_{3}}+\underset{\text { Bicarbonate }}{\mathrm{HCO}_{3}}
$$

\subsubsection{Heterotrophic Nitrification}

Heterotrophic nitrification is predominantly seen in acidic soils utilizing either organic or inorganic nitrogen compounds other than ammonia as substrates. It is assumed that acid-tolerant and acid-sensitive ammonium-oxidizing bacteria majorly contribute to the synthesis of nitrate in acid forest soils saturated with nitrogen. It is not coupled with energy conservation and has different enzymes than autotrophic nitrification. Organic nitrogen's heterotrophic nitrification contributes significantly to $\mathrm{N}_{2} \mathrm{O}$ emissions from soils having near neutral $\mathrm{pH}$, acidic $\mathrm{pH}$, and high organic matter (grasslands). Heterotrophic nitrification is proportional to $\mathrm{C}: \mathrm{N}$ ratio in the soil; i.e., higher $\mathrm{C} / \mathrm{N}$ contributes to greater heterotrophic nitrification rate. It is more in coniferous acidic forests than broad leaf acidic forest soils. Conversely, $\mathrm{NO}_{2}$ emission would be in higher concentration in pasture soils and arable soils than in forest soils due to the quantity of microbial community present and/or the organic $\mathrm{N}$, C content available (Zhang et al. 2015). Bacterial and fungal genera like Absidia and Alcaligenes, Arthrobacter, Aspergillus, Paenibacillus, Paracoccus, Pseudomonas, Thiosphaera, and Verticillium are involved in heterotrophic nitrification (Siddarame 
Gowda et al. 1977; Moir et al. 1996; Brierley and Wood 2001; Behrendt et al. 2010; Dilfuza 2018).

$\underset{\text { Organic/Inorganic }}{\text { Organic } \mathrm{N} / \text { Inorganic }} \underset{\mathrm{N}}{\mathrm{N}} \rightarrow \underset{\text { Hydroxylaming }}{\mathrm{NH}_{2} \mathrm{OH}} \rightarrow \underset{\text { Nitrate }}{\mathrm{NO}_{3}}$

\subsubsection{Denitrification}

It is an anaerobic reduction step where bioavailable nitrogen, i.e., nitrate, is reduced to bioinert form, i.e., dinitrogen gas. This reduction step utilizes energy, produce intermediates such as nitrous oxide, nitric oxide, etc being greenhouse gases that are players in air pollution and react with ozone. It is carried out not only by chemoorganotrophic prokaryotes, like few species of Aerobacter, Bacillus, Pseudomonas, Klebsiella, Escherichia coli, Paracoccus, Thiobacillus, Thiomargarita, and Thioploca (T. araucae and T. ingrica species), but also by some fungal members of Ascomycota and Basidiomycota (Risgaard-Petersen et al. 2006; David et al. 2014; Danovaro et al. 2017). Denitrifiers contain enzyme nitrate reductase, which can be membrane-bound nitrate reductase (NAR) and/or periplasmic nitrate reductase (NAP) responsible for catalyzing dissimilatory nitrate reduction to nitrite. Microorganisms like Beggiatoa reduce nitrate to ammonium via nitrite. NAR can be considered a transmembrane protein as it has cytoplasmic catalytic dimer encoding nar $G, H$ and a membrane-bound protein anchoring between cytoplasm and periplasm encoding narI, which transfers protons to periplasm, and hence proton motive force is seen. In agriculture, denitrification is detrimental as most of the nitrate in fertilizer is lost, while it is beneficial in wastewater treatment.

$$
\begin{aligned}
& \underset{\text { Nitrate }}{\mathrm{NO}_{3^{-}}} \rightarrow \underset{\text { Nitrite }}{\mathrm{NO}_{2^{-}}} \rightarrow \underset{\text { Nitric oxide }}{\mathrm{NO}} \rightarrow \underset{\text { Nitrous oxide }}{\mathrm{N}_{2} \mathrm{O}} \rightarrow \underset{\text { Dinitrogen }}{\mathrm{N}_{2}} \\
& 10 \mathrm{e}^{-}+12 \mathrm{H}^{+} \rightarrow 6 \mathrm{H}_{2} \mathrm{O}
\end{aligned}
$$

It can also be understood as the anaerobic respiration of nitrite, nitric oxide, and nitrous oxide to dinitrogen. Microorganisms carrying out all the three reactions are termed as classical or canonical denitrifiers. Nitrous oxide reductases (NOS) present in the periplasm of diverse bacterial species have diverse NOS variants. Inhibition of NOS resulted in nitrous oxide emission during reduction of nitrate to nitrogen by denitrifiers. Nitric oxide reduction is catalyzed by heme-copper oxidases containing cytochrome c-dependent nitric oxide reductase (cNOR), quinol-dependent qNOR, and copper-containing CuANOR. There exists an unusual qNOR, viz., nitric oxide dismutase (NO-D), that catalyzes dismutation of nitric oxide to dinitrogen and oxygen gas, a lesser known process in organisms like Candidatus Methylomirabilis oxyfera.

Certain bacteria and archaea do not complete the pathway, and this results in the release of greenhouse nitrogenous gases to the environment, like ammonia-oxidizing 
chemolithotrophic bacteria that reduce nitrite to nitrous oxide, while eukaryotes such as fungi and foraminifers reduce nitrite/nitrate to nitrous oxide/dinitrogen, respectively. A denitrifying intra-oxygenic methanotroph, Candidatus Methylomirabilis oxyfera found in anoxic environment, reduces nitrous oxide to dinitrogen without producing an intermediate by utilizing methane as a source of energy, reductant and carbon (Lisa and Martin 2016; Dilfuza 2018; Marcel et al. 2018).

\subsubsection{Ammonification}

Various fungi and prokaryotes decompose organic nitrogen from dead and decaying organisms, excreta etc. to inorganic bioavailable nitrogen form, ammonia. This process of converting complex organic nitrogenous compounds such as proteins, vitamins, nucleic acids and urea to simple available nitrogenous forms like ammonia and ammonium ion is known as ammonification. Nitrogen is returned to the ecosystem by enzymes such as proteases, nucleases and ureases of different heterotrophic fungi and bacteria like Bacillus, Microbacterium, Streptomyces, Clostridium, Proteus, Pseudomonas, Zygorhynchus, Penicillium, Rhizopus etc. (Jeanette and Joshua 2011; Dilfuza 2018).

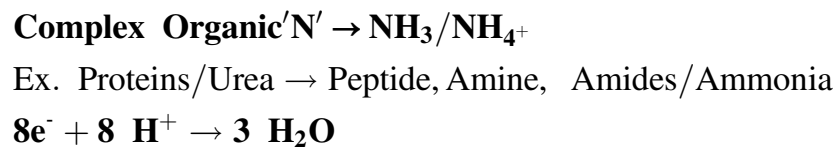

Ammonia fungi are the chemoecological group of fungi that exclusively develop their reproductive structure or fruiting bodies when soils are rich in ammonia, urea, and other nitrogenous compounds. Examples include (1) early-phase fungi-anamorphic and cup fungi in Ascomycota when ammonium content in soil was decreased to $\mathrm{pH}-7$ - and (2) late stage of early-phase fungi-with the oxidation of ammonia and decrease in $\mathrm{pH}$ from 7 to 6, Basidiomycota were in larger number and still decrease in $\mathrm{pH}$ witnessed in late-phase fungal species with larger fruiting bodies. Previous studies have shown that early-phase species Amblyosporium botrytis and Ascobolus denudatus had deadlock competition/inhibition with nonammonium fungi Aspergillus niger and Penicillium citrinum on substrate-containing urea while medium and weak competition in ammonium-, nitrite-, and nitrate-containing media (Barua et al. 2012).

\subsection{Dissimilatory and Assimilatory Nitrate Reduction to Ammonia (DNRA and ANRA)}

DNRA can be defined as reduction of nitrite to ammonia or ammonium ions at cellular level or between organisms in a community utilizing dehydrogenases, which evolved from respiratory homologous multiheme cytochrome $\mathrm{c}$ reductases with $n r f A$ 
gene product. It is stimulated by negative redox potential and removes or reduces the loss of dinitrogen from soil by conserving energy and generating proton motive force for cellular growth. DNRA to ammonium is catalyzed by periplasmic cytochrome $\mathrm{c}$ nitrite reductase (ccNIR) encoded by $n r f A H$, octahaem nitrite reductase (ONR), or octahaem tetrathionate reductase (OTR). ANRA is similar to DNRA except that the enzymes participating would be nitrite reductases that are evolutionarily unrelated from bacteria and/or fungi. Microbes carrying ANRA utilize assimilatory cytoplasmic ferredoxin or NADH-dependent nitrite reductases with a single siroheme and an iron-sulphur [4Fe-4S] center containing nirA of Cyanobacteria, $\varepsilon$ Proteobacteria, or nirB/nasB gene product of $\beta$ - and $\gamma$ - Proteobacteria, respectively (Zhang et al. 2013; Lisa and Martin 2016; Marcel et al. 2018).

$$
\underset{\text { Nitrate }}{\mathrm{NO}_{3^{-}}} \rightarrow \underset{\text { Nitrite }}{\mathrm{NO}_{2^{-}}} \rightarrow \underset{\text { Ammonium }}{\mathrm{NH}_{4^{+}}}
$$

Recent metagenomic and microscopic studies have shown that the volcanic eruption consists of different genera of prokaryotes and eukaryotes that can be involved in different metabolic pathways for the uptake of sulfur and nitrogen compounds. Of the different microorganisms reported in this study, it was observed that Thiolava veneris has genes for both dissimilatory and assimilatory nitrate reduction (Philippot and Germon 2005; Danovaro et al. 2017).

\subsection{Codenitrification}

The microbially mediated cosynthesis of $\mathrm{N}_{2} \mathrm{O}$ and $\mathrm{N}_{2}$ via $\mathrm{N}$-nitrozation reaction is known as codenitrification, where fungi play a significant role over bacteria. Fusarium oxysporum converts $\mathrm{N}$ compounds like azide, salicylhydroxamic acid and ammonium ions to either $\mathrm{N}_{2} \mathrm{O}$ or $\mathrm{N}_{2}$, which will then combine with another $\mathrm{N}$ atom from nitrite to form a hybrid $\mathrm{N}_{2} \mathrm{O}$ species. It is considered to be a potentially significant process in all the three domains, viz., Archaea, Bacteria, and Fungi in Eukarya. Most of the codenitrifying bacterial and fungal species, such as Pseudomonas spp., Fusarium solani, Cylindrocarpon tonkinense, Fusarium spp., Streptomyces etc. are already known as typical denitrifiers. It is a process where nitrogen gas is formed by a variety of possible biotic nitrozation reactions, i.e., N-N or N-C nitrozation reactions. Bionitrozation is another nitrozation reaction as a result of which release of nitrogen gas or immobilization of nitrogen is seen, independently of participating microbial species or environmental conditions (Tanimoto et al. 1992; Masahito et al. 2007; Oliver et al. 2011).

$$
\begin{array}{llllll}
\mathrm{NO}_{2}^{-} / \mathrm{NO} & \rightarrow & \mathrm{N} & \square & \mathrm{N}_{2} \\
\mathrm{~N}_{2} \mathrm{O} & \text { Nitrate/Nitric oxide, Nitrous oxide } & \rightarrow & \mathrm{N}_{\text {Nitrogen }} & & \text { Dinitrogen }
\end{array}
$$




\subsection{Microbial Diversity: N Cycle}

Both culture-dependent and independent techniques can be used to understand the microbial diversity involved in $\mathrm{N}$ cycle. Usually, traditional pure culture techniques include (1) modified $\mathrm{N}$-free solid/semi-solid media for the isolation of $\mathrm{N}$ fixers, followed by acetylene reduction assay; (2) ammonia-oxidizing bacteria (AOB) and archaea on AOB media (John and Robert 1936); (3) ammonia producers on routine growth medium (RGM) or hyperammonia producers on selective/enrichment (SE) medium; and (4) identification of nitrate or nitrite producers using nitrosamine strips in peptone broth (Terence and Michael 2003). Nitrogen fixation can also be assessed by crown- and lateral-nodulation count in nodulating plants, measuring acetylene reduction after $4 \mathrm{~h}$ of sunrise, measuring cobalamin (Raven and Barkhem 1974), calculating GHG flux by static gas chambers, calculating Co by AAS, measuring leghemoglobin (Coventry and Dilworth 1976), and calculating available $\mathrm{N}$ by Kjeldahl method (Dilworth et al. 1978).

The presence of nase genes in $\mathrm{N}$ fixers has been carried out at varied habitats like soils, plants, lakes, rivers, oceans, invertebrate guts, bioreactors, etc. (Zehr et al. 2003). Short-term changes, for example, in nitrifying activities, can be known via specific proteomic approach by extracting, purifying and assaying significant enzymes like AMO and NXR. If the enzymes are membrane bound, then indirect quantifying activity of the enzyme or activity-based protein profile can be carried out (Norton and Yang 2019). Relevant biochemical and physiological characteristics of an environment can be determined by using pure cultures. Other culture-independent techniques include utilization of $\mathrm{N}^{15}$ nitrogen isotope, known as $\mathrm{N}$ fixing probes for rRNA phylotypes or gene sequences for nitrogenase. The relation and contribution of microbial process to $\mathrm{N}$ cycle can be estimated via stable isotopes, specific assays, and selective inhibitor techniques on the basis of the metabolism and enzyme properties of microbes responsible for $\mathrm{N}$ transformation. Metal homeostasis studies can be carried out to know the role or significance of metal cofactors such as V, Mo, or alternate metals for biological nitrogen fixation (BNF) in nitrogenase. Enzyme activity can be demonstrated via isotopic fractionation technique like isotopic acetylene reduction assay (ISARA) (Romain et al. 2017). For the analysis of specific metabolites, methods like isotope pool dilution (IPD) and hydrolytic activity assay for specific amino sugars and amino acid enantiomers at varied temperatures in $\mathrm{N}^{15}$ labeled media to analyze free amino groups, soil-free amino acids, total amino sugar, and amino acid content can be used. PLFA (phospholipid fatty acid analysis) profile followed by gas chromatography (GC) and ISQ single quadrupole mass spectrometer can be used to analyze microbial communities that are involved in $\mathrm{N}$ cycle (Yuntao et al. 2018).

Biochemical and gene-based coupling studies can also be used to determine the presence of nitrogen fixers by nif and of AOB by amo primers. Ammonia synthesis or evolution can be analyzed by peptone broth and quantitatively by indophenol spectrophotometry. Nitrite production can be confirmed by Griess reagent, and nitrate/nitrite concentration can be known by ion exchange chromatography. Primers are designed using degenerate oligonucleotides or modified nucleotides that enable 
us to estimate and determine nitrogen-cycle-related microbes quantitatively (Shinn 1941; Poly et al. 2001; Baldani and Baldani 2005; Hirotsugu et al. 2015).

Not all the microbes are culturable, even after the development of few new methods by Zengler and coworkers which combined culture-based and molecular techniques to clearly understand the actual roles of microbes in $\mathrm{N}$ cycle. Conversely, molecular techniques to study microorganisms (both culturable and nonculturable) involved in N cycle include DNA isolation, PCR amplification, Sanger sequencing (of pure cultured isolates, which should be carried out to know further details about the organisms), DGGE (denaturing gradient gel electrophoresis), cloning, DNA arrays, FISH (fluorescent in situ hybridization), NGS (next-generation sequencing), or high throughput sequencing. For qPCR analysis, RT-PCR provides information about the distribution of microorganisms involved in $\mathrm{N}$ cycle across varied habitats, while phylogenetic analysis requires bioinformatics parallelly, along with results obtained from NGS, DGGE, restriction fragment length polymorphism (RFLP), DNA microarrays, library preparation by cloning, and sequencing. The $16 \mathrm{~S}$ rRNA gene is involved in molecular analysis via targeted metagenomics by sequencebased and function-based approaches involving-sample preparation, purification, separation, sequencing, data analysis, and interpretation. NGS/HTS is carried out via Roche 454 Genome Sequencer, HiSeq 2000, and AB SOLiD ${ }^{\mathrm{TM}}$ system. DNA-based stable isotope probing (DNA-SIP) approach was used to study six grass species. It revealed a variation of $\mathrm{N}$ uptake in conservative and exploited species, which was also related to root exudation levels. Furthermore, metatranscriptomics approach is being used to evaluate functional abundance and diversity changes related to $\mathrm{N}$ cycle. Additionally, metaproteomics provides protein fingerprints via mass spectrometry. Meta-analysis still deals with challenges with sampling and data procurement (Wang et al. 2017; Nicholas and Babalola 2018).

\subsection{Different Ecosystems: Microbial Diversity (Gene Based) and N Cycle}

\subsubsection{Forest Ecosystem}

Ammonia-oxidizing archaea (AOA) of the marine Crenarchaeota group affiliated to groups 1.1a and 1.1b are significant in the oxidation of ammonia in forest soils. Forest soils contain greater nifH abundance than agricultural soils. Tropical forests contain leguminous trees, which constitute symbiotic nitrogen fixers, while coniferous forests dominate free-living nitrogen fixers, except Frankia-Alder symbiotic diazotrophy. Acid forest soils have less nifH abundance. Rosch et al. (2002) observed that acid forest soils contained nifH from highly conserved symbiotic and nonsymbiotic diazotrophs. It is known that the abundance of free-living diazotrophs results in greater soil nitrogen than fertilization. Studies carried out by Wang et al. (2013) suggested the presence of distinct communities of nifH from different ecosystems like subtropical wet forests, dry forests, grasslands, boreal 
forests, etc., usually driven by $\mathrm{pH}$, annual precipitation, annual temperature, sunlight exposure and soil organic matter, i.e., C:N ratio (David et al. 2014).

Nitrification is carried out by chemolithotrophic ammonia oxidizers-bacteria and archaea - and nitrite oxidizers. Nitrosospira sp. clusters 1, 2, 3, and 4 predominate AOB amoA in forest soils. AOA and Crenarchaeota affiliated to groups 1.1a and $1.1 \mathrm{~b}$ are significant in the oxidation of ammonia in forest soils. The amoA of AOA copies are 16 times higher in sandy grasslands with a $\mathrm{pH}$ of 7 than in arable grasslands with $\mathrm{pH}$ 5.5. In silty clay, AOA is one to ten times higher in abundance than AOB in clay agri-undic soil, which is similar to that in semi-arid soil. Archaeal nitrifiers are directly correlated with $\mathrm{N}_{2} \mathrm{O}$ flux in the forest ecosystem (David et al. 2014).

$\mathrm{N}_{2} \mathrm{O}$ emission and fungal:bacterial ratio is higher in low $\mathrm{pH}$ soils, either in forest soil or drained peatland soil. Rosch et al. (2002) suggested an effective link between biological nitrogen fixation and denitrification by $n i r S$ and $n o s Z ; n i r S$ and $n i r K$ gene diversity is low in oak and spruce, i.e., acid forests. Positive correlation of napA gene is observed with exchangeable manganese $(\mathrm{Mn})$ and soil $\mathrm{C}$; narG is positively correlated with soil C. Various factors influence the quantity or concentration of nirS and nirK, like soil moisture; soil temperature; total N; available $\mathrm{P}$, ammonium, nitrate, soil organic matter, dissolved organic carbon; and soil $\mathrm{pH}$. Forest soils have abundant nosZ, while agricultural soils are home to nirS. Nitrogen addition via ammonical sulfates reduces soil $\mathrm{pH}$, leading to lowered narG, nirK, nirS, and $n o s Z$, while the addition of organic fertilizers increases soil $\mathrm{pH}$ to near neutral, thereby increasing narG, nirK, and nosZ abundance (David et al. 2014).

\subsubsection{Agroecosystems}

The effects of the application and management of nitrogen can be apparently observed in the farming, in wild plants, in the health of all living beings, and in economic and social domains (Robertson and Vitousek 2009; Foley et al. 2011). Reduced soil organic carbon, crop production and greater erosion are result of poor land management practices, which lead to a reduction in biological diversity. Agroecosystems are managed by efficient or substitution approaches that focus on alternative practices in order to reduce or replace external, synthetic and nonrenewable inputs, and increase ecofunctional intensification. Other practices include efficient $\mathrm{N}$ utilization by biological nitrogen fixers that help maintain soil biota, timebased fertilizer application and decreased soilborne pathogens by bioactive amendments in soil-like manure, compost etc. Integrated crop management practices include the use of a push-pull cropping system in order to distract pests from primary crops, conservation agriculture practices such as crop rotation, mixing of legumes, perennial/annual cropping, implementation of a zero-till system, reducing soil disturbance by direct seeding, maintained grazing of animals, and reducing pathogen effect by integrated pest management through utilization of genetically less susceptible/resistant varieties (Lampkin et al. 2015). However, greater quantities of nutrients, energy, and water are required for mechanical- and chemical-intensive 
agriculture, i.e., ecological intensification (Abdullah et al. 2017). Response to changes in the environment can be explored via an integrative approach toward functional traits, soil conditions, microbial diversity and community dynamics (Espenberg et al. 2018). Several model fungal nitrate assimilations and regulations are well known, whereas the contribution of fungi in total nitrogen cycling in agricultural soils is under study. It is a well-known fact that fungal-dominated agricultural systems are less prone to leaching and denitrification. Available carbon in addition to fungal assimilatory nitrate reductase plays a crucial role where a horizontal gene transfer event is commonly observed (Markus et al. 2014).

\subsubsection{Agroecosystem: Legume-Cultivated Soils}

Microbes inhabit or colonize in leguminous plants, forming plant-microbe complexes known as holobiomes. They increase yield; promote growth; enhance nutrient uptake; enable fixation by nodules; improve $\mathrm{CO}_{2}$ sequestration from air; impart resistance toward biotic stresses like pests, diseases, and abiotic stress; improve plants' photosynthetic capacity etc. These are referred to as EPHs (enhanced plant holobiomes) when the association is with a purpose. Legumerelated microbial EPHs are usually seen in (a) bacteria from Rhizobiaceae, (b) plant obligate arbuscular mycorrhizal fungi (AMF), (c) selected endophytic strains of Trichoderma, and (d) fungi from order Sebicales, especially Piriformospora indica (Gary and Norman 2019). Each of these organisms produces chemical-signaling molecules, viz., SAMPs and MAMPs (symbiont-associated and microbial-associated molecular patterns). EPH-induced plant defense systems include (1) improved upregulated defense gene expression-mpk3, mpk6, wrky22, $w r k y 29$, and $p d f 1.2$ - via quorum sensing and increased release of antifungal phenol compounds and $\mathrm{H}_{2} \mathrm{O}_{2}$; (2) induction of systemic resistance; and (3) hormonal signaling, leading to acquired systemic resistance (Abraham and Babalola 2019).

Genes like nosZ, nifH, amoA, nirK and nirS were abundant in bulk soil, while nifH, amoA, hao, narG, nirS/K, norB, and nos Z were abundant in maize rhizospheric soils. Abundance of nos $Z$ and bacterial amoA genes was observed in organically amended soils. Soils with higher organic carbon content showed increased $n r f A$ and nosZ genes (Jennifer et al. 2019). N-fertilized soils have abundant AOA and AOB, while $n x r B$ abundance was not affected by $\mathrm{N}$ fertilization. Repeated ammoniumsulfate-based fertilized soils have higher AOB as a result of nitrification than AOA. Among the treatments, the difference was insignificant. Plants take either nitrate or ammonium, which in turn affects the community and diversity of nitrifiers. Nitrogen transformations were more significant in rhizospheric soils as against bulk soils. Certain plants secrete nitrification inhibitors in the rhizosphere, thereby reducing nitrification (Norton and Yang 2019). Nitrification is carried out by nifHDK and/or $p n f A$, which is a similar sigma factor; comparatively, Agrobacterium species colonizes Sesbania and rice plants having sym plasmid that comprises nifH and nodA genes (Nicholas and Babalola 2018). NirK was less abundant in legume-based 
soils, whereas amoA, narG, nirS, nosZ and nifH were in greater abundance. Meanwhile, amoA, narG, and nifH diversity was significantly affected. It is known that these soils have higher organic $\mathrm{C}$, nitrate, available potassium (K), and ammonium ion concentration, and lower available P. The more significantly found bacteria in such soils include Tumebacillus, Bacillus drentensis, Bradyrhizobium and Streptomyces (Zhou et al. 2019). Bacterial amoA, nirK and nirS genes abundance were observed in early vegetative stage, irrespective of fertilizer application, which decreased gradually with the passing of the developmental stages of plant and was lowest at flowering stage. Meanwhile, AOA was abundant in all stages, organic fertilizer application increased its abundance, nifH gene was abundant during the flowering stage when manure-based fertilizer was applied, and nirK and nirS genes were abundant in legume-cultivated soils (Hai et al. 2009).

\subsubsection{Agroecosystem: Paddy-Cultivated Soil}

As paddy is a staple crop cultivated by Asians, changes in microbial population in paddy soils bring about crucial variance globally. Most of the soil bacterial communities decreased with deeper layers of paddy soils; however, ammoniaoxidizing archaea (AOA) communities are enhanced. Genes belonging to AOA are in abundance than AOB genes in soils cultivated with paddy. In top-layer $(0-20 \mathrm{~cm})$ soil, nirS are abundant, while in deep layers, nirK is abundant. It is observed that variance in $\mathrm{N}$-cycling genes is a result of changing environmental conditions. It is known that $\mathrm{N}$-cycling gene abundance is related to the fertilizer applied, the type of soil used in cultivation, soil depth, and soil properties. Deeper soils generally witnessed low abundance of AOA and AOB genes, but up to a depth of $0-30 \mathrm{~cm}$, and the reverse is observed in ammonium-rich soils (Leininger et al. 2006; Hofferle et al. 2010). Abundance in nifH gradually decreases with depth. In deeper layers of soil, AOA amoA dominates AOB amoA copy number, shooting peak at $20-40 \mathrm{~cm}$ based on region and way of interaction. Increased abundance of nirK, AOA, and $16 \mathrm{~S}$ rRNA gene is directly proportional to the total $\mathrm{C}, \mathrm{N}, \mathrm{C} / \mathrm{N}$ ratio and inversely proportional to annual precipitation and frost-free period. Altitude and abundance of $18 \mathrm{~S}$ rRNA gene are negatively related; a remarkable positive correlation is found with $\mathrm{C} / \mathrm{N}$ ratio and $n i f H$, as well as changes in the abundance of $18 \mathrm{~S}$ rRNA and AOA. Soil physical structure is positively correlated with most microbial and $\mathrm{N}$-cycling functional genes, whereas negative correlation is observed with dissolved organic carbon (DOC) concentration and changes in nirS gene abundance. Abundance in AOA gene is positively correlated with nitrate concentration, soil water content, soil $\mathrm{pH}$, sand content and DOC in correlation with nirK gene. In rhizospheric and alkaline soils, $\operatorname{nirK}$ gene is abundant, while nirS is abundant in bulk and acidic soils (Henry et al. 2004; Barta et al. 2010; Wang et al. 2017).

\subsubsection{Terrestrial Antarctic Soils}

Studies in Antarctic soils revealed that the addition of nitrogen and temperature had a significant effect on microbial community diversity. Ammonia-oxidizing bacteria 
are quantitatively more than archaea in Antarctic soils. Fungi and archaea are mostly found in colder temperatures. Warm temperature reduces ammonia-oxidizing archaea $(\operatorname{amoA})$ and nitric oxide reductase $($ nor $B)$ genes and is even detrimental to ammonia-oxidizing archaea. Warm temperature increases nifH and nirK gene abundance, while nirS is less sensitive to it. Nitrogen addition increased nifH and nirK genes. Greater numbers of denitrifiers ( $n i r S$ and nirK) are observed upon nitrogen addition, whereas archaeal communities remain unaffected.

Nitrous oxide emissions usually depict a truncated denitrification pathway. Bacterial norB and nos $Z$ abundance is lesser than bacterial narG, nirS and nirK abundance due to the reduction of nitric or nitrous oxides, hence resulting in incomplete nitrogen pathway. The nirS gene is predominantly abundant than nirK; however, a significant increase in NirK abundance was observed if the temperature of soil was maintained at $10{ }^{\circ} \mathrm{C}$. Temperature plays a crucial role in denitrifying community size and composition. There are certain temperature-sensitive amoA communities, and a few of them can be made adaptive or less detrimental by favorable environmental factors like nutrients. Soils fertilized with nitrogen witnessed $a m o A$ at $4{ }^{\circ} \mathrm{C}$ and $\operatorname{nar} G$ at $10{ }^{\circ} \mathrm{C}$ (Jung et al. 2011).

\subsubsection{Tropical Peatland: Drained and Natural Soils}

Tropical peat can be defined as Histosol, i.e., with high organic $\mathrm{C}$ and low bulk density of approx. $0.2 \mathrm{mg} / \mathrm{m}^{3}$, which mostly contains carbon-water storage in tropical latitude covering Southeast Asia, Africa, and Central and South America. Peatland ecosystems are very much affected by climate changes, anthropogenic activities like logging and building of drainage, and land conversions to agriculture. Denitrification or conversion of nitrous oxide to dinitrogen in natural tropical peatlands is usually controlled by nos $Z$ clade I genes and in drained peatland soils by clade II genes mainly. Archaeal abundance is observed in drained peatlands, while bacteria are dominant in natural peatland soils. Genera Mycobacterium, Conexibacter, Burkholderia, Rhodoplanes, Pseudomonas and Paenibacillus of bacterial phyla Proteobacteria, Actinobacteria, Acidobacteria and Firmicutes are dominant in both natural and drained peatland soils. NirS, nirK, nosZ I, nosZII, nifH, and archaeal $a m o A$ genes are abundantly found in both soils, while $n r f A$ is seen in natural peatland soils only. Bacterial $a m o A$ is not seen in peatland soils. Drained peatland soils are comprised mostly of archaeal community, while natural peatland soils comprise both bacterial and archaeal communities equally. Warm temperature favored AOA than $\mathrm{AOB}$, just like acidic tea orchards and forest soils ( $\mathrm{Lu}$ et al. 2012; Wu et al. 2013). This AOA abundance can be related to chemical properties of soil like temperature, $\mathrm{pH}$, and available $\mathrm{C}, \mathrm{O}$, and $\mathrm{N}$ content. Anammox has a very minor role here (Espenberg et al. 2018). 


\subsection{Strategies to Maintain N Equilibrium}

Principal $\mathrm{N}$ management practices include the application of the 4R approach — right source, right rate, right time, and right place (Clarke and Beegle 2014). Excess fertilizer-based reactive nitrogen $(\mathrm{Nr})$ contributes to wash off or runoff, leading to (1) accumulation as nitrate form in drainage or waste and atmospheric deposition of denitrified dinitrogen and nitrous oxide (GHG); (2) emission of trace amounts as ammonia and nitrogen oxides in the atmosphere, which paves the way for secondary pollutants like ammonical nitrates and sulfates, aerosols, ozone, and photochemical oxidants; and (3) sedimentation in water bodies as a result of leaching. These forms are available for a few weeks in the atmosphere and a few decades in terrestrial ecosystems, and the longest are in oceans, which are difficult to be controlled (Fowler et al. 2013 and Huhe Borjigin et al. 2016). Therefore, alternate strategies for nitrogen use efficiency (NUE), along with biotic and abiotic factors, need to be worked out in order to maintain $\mathrm{N}$ equilibrium.

Blanket usage of $\mathrm{N}$ chemical fertilizers; variations of climatic conditions and the conditions of soil and crops and their cultivars; and conventional management practices lead to excess $\mathrm{N}$ application, which has an impact on NUE and thereby adds more $\mathrm{Nr}$ to the environment. Therefore, proper agronomical practices and methods that are less prone to leaching and volatilization and retain available $\mathrm{N}$ for the plants can lead to sustainable agriculture and $\mathrm{N}$ equilibria in the environment. Understanding management strategies based on the ability of soils to emit or mitigate $\mathrm{N}_{2} \mathrm{O}(\mathrm{GHG})$ is also important. Another approach that can be suggested, depending on the environmental conditions of a particular site, is an alternate legume-based cropping system which will automatically replenish nitrogen-based microbial community in the soils. Alternatively, organically coated urea/fertilizers can also be used which will serve as slow/controlled release urea; application of nitrification inhibitors to soils or modified fertilizer practices like Karanj oil coating, N-(n-butyl) thiophosphoric triamide (NBPT) coating, allicin coating, use of dicyandiamide (DCD), 3,4-dimethylpyrazole phosphate (DMPP), or nitrapyrin; etc. have inhibitory effect on nitrification and soil urease (Ranitha et al. 2017; Shilpha et al. 2017; Wang et al. 2018; Yaying et al. 2018).

\subsection{Conclusion}

Nitrogen occupies more than two-third part of the atmosphere and is in an unavailable form. Besides, its presence in every cell of living beings in different stable forms, combined with various elements, demonstrates its importance. Nitrogen circulates globally in three major ways: (1) nitrogen fixation, (2) nitrification, and (3) denitrification, apart from other lesser known processes. Anthropogenic activities 
such as return of animal waste to soil, wastewater treatment, application of chemicalbased nitrogen in the form of fertilizers and fossil fuel combustion have led to the disturbance of $\mathrm{N}$ cycle. Percolation of nitrogen into the deeper layer and water streams, especially the biosphere region, led to a shift to isotopically light nitrogen in lake sediments and heavy nitrogen in temperate regions. There is a possibility of an "open" $\mathrm{N}$ cycle instead of a "closed" $\mathrm{N}$ cycle due to excessive fertilization; leakage of natural $\mathrm{N}$ (denitrification); inhibition of natural $\mathrm{N}$ deposition/fixation, which would disturb the food web or energy pyramid; global temperature increase leading to changes in gaseous composition in the atmosphere, which in turn may have negative effects on vegetation and positive effects for certain vegetation. In addition, $\mathrm{N}_{2} \mathrm{O}$ accounts for $0.03 \%$ of the total GHG emission. It has 300 -fold greater potential for causing global warming due to its radiative forcing capacity compared with other GHGs. Hence, in order to maintain an environmental equilibria status of $\mathrm{N}$ cycle, understanding the diversity of microorganisms involved in $\mathrm{N}$ cycling is fundamental for sustainable environmental management. Recent studies and molecular methodologies have led to a better understanding of the role of the different microorganisms in $\mathrm{N}$ cycle.

\subsection{Future Perspective}

In order to understand microbial diversity and its impact on environmental $\mathrm{N}$ equilibria in the midst of a fluctuating environment, it is necessary to understand and link deeper physiological processes that involve different microbial subpopulations. It is important to study a broader range of samples (i.e., more than one site) and conduct quantitative in situ studies on the primary reactions of $\mathrm{N}$ cycle and lesser known processes like anammox, comammox, and codenitrification, along with the function of microbial extracellular enzymes. Interactive studies between $\mathrm{N}$ fixers, nitrifiers, ammonifiers, denitrifiers, and anammox communities in varied environmental conditions will decrease the knowledge gap and facilitate our understanding of the natural distribution pattern of microorganisms. Different experimental set up can be planned by varying different concentrations of nutrients $(\mathrm{N}, \mathrm{P}, \mathrm{K}$ and microelements); their interactive effect on culturable and non-culturable diversity of microorganisms and their correlation with global $\mathrm{N}$ cycle and other geochemical cycles can be implicated (Table 13.1). 
Table 13.1 Genes involved in $\mathrm{N}$ cycle

\begin{tabular}{|c|c|}
\hline Name of genes & Details of genes \\
\hline $\begin{array}{l}\text { nifD, } K, H \text {, vnfDGK and } \\
\text { anfHDK }\end{array}$ & $\begin{array}{l}\text { Nitrification-Mo-nitrogenase, vanadium nitrogenase, and Fe-only } \\
\text { nitrogenase major cluster genes }\end{array}$ \\
\hline$n f H, v n f H$, and $n i f H$ & $\begin{array}{l}\text { Nitrogenase reductase or Fe protein-Fe-containing electron transfer } \\
\text { protein, used as a genetic marker for nitrogen fixers }\end{array}$ \\
\hline $\begin{array}{l}\text { ifD, } K ; \text { vnfDGK; and } \\
\text { anfDK }\end{array}$ & $\begin{array}{l}\text { Encodes catalytic component of nitrogenase with Fe, V, and Mo in } \\
\text { active center }\end{array}$ \\
\hline nifQXWE-XQVY & $\begin{array}{l}\text { Mo-nitrogenase minor cluster genes-for synthesis and insertion of } \\
\text { FeMo cofactor into FeMo protein }\end{array}$ \\
\hline ifENB & Helps in nitrogenase cofactor synthesis \\
\hline odA & Nodulation gene \\
\hline pnfA & $\begin{array}{l}\text { Nitrogenase-electron transfer/ } \mathrm{O}_{2} \text { protection, thereby controlling } \\
\text { nitrogenase activity }\end{array}$ \\
\hline hesB & Fe-S cluster assembly protein \\
\hline cysE & Serine acetyltransferase \\
\hline hh & Hydrazine hydrolase \\
\hline hzo & Hydrazine oxidoreductase \\
\hline amoA, $B, C$ & Ammonia monooxygenase-subunits A, B, C \\
\hline pmoA, $B, C$ & Methane monooxygenase-subunits A, B, C \\
\hline camoA & Nitrification by comammox \\
\hline norB, $C$ & Nitric oxide reductase-subunit $\mathrm{B}$, subunit $\mathrm{C}$ \\
\hline hao & Hydroxylamine dehydrogenase \\
\hline nir-nirA & Nitrite assimilation-ferredoxin nitrite reductase \\
\hline $\operatorname{nir} B, D, K / S$ & $\begin{array}{l}\text { Nitrate reductase—(NADH) large subunit, small subunit, } \\
\text { (NO) forming/nitrite assimilation—(NO) forming hydroxylamine } \\
\text { reductase }\end{array}$ \\
\hline nor & Nitric oxide reductase \\
\hline nos $Z$ & Nitrous-oxide reductase \\
\hline napA, napB & Periplasmic nitrate reductase, cytochrome c-type protein \\
\hline $\begin{array}{l}\text { narG, } \text { narH, narL, } \\
\text { narJ }\end{array}$ & Nitrate reductase $-\alpha$ subunit, $\beta$ subunit, $\gamma$ subunit, $\delta$ subunit \\
\hline $\operatorname{narG}, H$ & Nitrate reductase catalytic dimer, $n a r G$ to detect denitrifiers \\
\hline narI & Membrane-bound nitrate reductase-codes membrane anchor \\
\hline$n x r$ & Nitrite: nitrate oxidoreductase \\
\hline nas-nas $A$, nasB & $\begin{array}{l}\text { Assimilatory nitrate reductase—catalytic subunit, electron transfer } \\
\text { subunit }(\mathrm{NADP}(\mathrm{H}))\end{array}$ \\
\hline$h z s A, B$ and $C$ & $\begin{array}{l}\text { Hydrazine synthase }-h z s A \text { and } B \text { to detect anaerobic ammonia } \\
\text { oxidizers }\end{array}$ \\
\hline nar & Assimilatory nitrite reductase \\
\hline $\operatorname{gln} A$ & Glutamine synthetase \\
\hline$g \ln P, H$ & Glutamine transporter gene \\
\hline glu2 & Glutamate synthase ferredoxin \\
\hline gltB & Glutamate synthase large chain \\
\hline gltD & Glutamate synthase small chain \\
\hline amt & Ammonium transporter \\
\hline
\end{tabular}


Table 13.1 (continued)

\begin{tabular}{l|l}
\hline Name of genes & Details of genes \\
\hline$g d h A$ & Glutamate dehydrogenase \\
\hline gudB & Glutamate dehydrogenase \\
\hline$n r t$ & Extracellular nitrate transporter \\
\hline$n a r B$ & Ferredoxin-nitrate reductase \\
\hline$n r f A$ & Dissimilatory nitrate reduction to ammonia (DNRA) \\
\hline nap & Denitrification \\
\hline ShiA & Mineralization \\
\hline
\end{tabular}

Sources: David et al. (2014), Holger et al. (2015), Inoue et al. (2015), Lisa and Martin (2016), Olivia et al. (2017), Florence et al. (2018), Marcel et al. (2018), Ramiro and Silvia (2018), Black et al. (2019) and Yan et al. (2020)

\section{References}

Abdullah A, Colin T, Amadou M, Sandeep K, Osborne S, Schumacher T (2017) Intensified agroecosystems and changes in soil carbon dynamics. In: Soil health and intensification of agroecosystems. Academic Press, Cambridge, pp 195-214

Abraham KO, Babalola OO (2019) Bacteria, fungi and archaea domains in rhizospheric soil and their effects in enhancing agricultural productivity. Int J Environ Res Public Health 16(20):3873

Abrol YP, Adhya TK, Aneja VP, Raghuram N, Himanshu P, Kulshrestha U, Chhemendra S, Singh B (2017) Sources of reactive nitrogen, environmental and climate effects, management options, and policies. The Indian nitrogen assessment. Elsevier, Amsterdam. Edn-1. ISBN: 978-0-12811836-8

Baldani JI, Baldani VLD (2005) History on the biological nitrogen fixation research in graminaceous plants: special emphasis on the Brazilian experience. Ann Braz Acad Sci 77 (3):549-579

Barta J, Tereza M, Daniel V, Tomas P, Hana S (2010) Effect of pH and dissolved organic matter on the abundance of nirK and nirS denitrifiers in spruce forest soil. Biogeochemistry 101:123-132

Barua BS, Suzuki A, Hoang PN (2012) Effects of different nitrogen sources on interactions between ammonia fungi and non ammonia fungi. Mycology 3(1):36-53

Behrendt U, Peter S, Michaela S, Rudiger P, Augustina J, Cathrin S, Petra S, Christine M, Andreas U (2010) Characterization of heterotrophic nitrifying bacteria with respiratory ammonification and denitrification activity - description of Paenibacillus uliginis sp. nov., an inhabitant of fen peat soil and Paenibacillus purispatii sp. nov., isolated from a spacecraft assembly clean room. Syst Appl Microbiol 33(6):328-336

Black EM, Chimenti MS, Just CL (2019) Metagenomic analysis of nitrogen-cycling genes in upper Mississippi river sediment with mussel assemblages. Microbiol Open 8(5):e00739, PMID: 30270525

Brierley EDR, Wood M (2001) Heterotrophic nitrification in an acid forest soil: isolation and characterisation of a nitrifying bacterium. Soil Biol Biochem 33(10):1403-1409

Campo RJ, Albino UB, Hungria M (2000) Importance of molybdenum and cobalt to the biological nitrogen fixation. Curr Plant Sci Biotechnol Agric 33:597-598

Chen DL, Chalk PM, Freney JR, Luo QX (1998) Nitrogen transformations in a flooded soil in the presence and absence of rice plants: 1.Nitrification. Nutr Cycl Agroecosyst 51:259-267

Clarke K, Beegle DB (2014) Nutrient management to improve nitrogen use efficiency and reduce environmental losses. Agronomy Facts 76:EE0094 
Coventry DR, Dilworth MJ (1976) Synthesis and turnover of leghaemoglobin in lupin root nodules. Biochim Biophys Acta 447(1(20)):1-10

Danovaro R, Miquel C, Michael T, Antonio D, Cristina G, Galderic L, David A, Sanchez-Vidal A, Jaime F, Antoni MC, Pedrosa R, Jesus R, Xavier R, Cinzia C (2017) A submarine volcanic eruption leads to a novel microbial habitat. Nat Ecol Evol 1:0144

David JL-B, Cindy EP, Susan JG (2014) Microbial functional genes involved in nitrogen fixation, nitrification and denitrification in forest ecosystems. Soil Biol Biochem 75:11-25

Dilfuza E (2018) Role of microorganisms in nitrogen cycling in soils. In: Soil Nutrients. Nova Science Publishers, Inc., New York, ISBN 978-1-61324-785-3

Dilworth MJ, Robson AD, Chatel DL (1978) Cobalt and nitrogen fixation in Lupinus angustifolius L. II nodule formation and function. New Phytol 83:63-79

Espenberg M, Marika T, Mander U, Kasak K, Novlak H, Teele L, Kristjan O, Maddison M, Jaak T (2018) Differences in microbial community structure and nitrogen cycling in natural and drained tropical peatland soils. Sci Rep 8(1):4742, PMCID: PMC5856767

Florence M, Alexander BA, Natasha P, Lance CS, John WP (2018) Exploring the alternatives of biological nitrogen fixation. Metallomics 10:523-538

Foley A, Navin R, Kate AB, Emily SA, Gerber SJ, Johnston M, Mueller ND, Christine OC, Deepak KR, Paul CW, Balzer C, Bennett EM, Stephen RC, Jason H, Monfreda C, Stephen P, Johan R, John S, Stefan S, David T, David PZ (2011) Solutions for a cultivated planet. Nature 478:337-342

Fowler D, Coyle M, Skiba U, Sutton MA, Cape JN, Reis S, Sheppard LJ, Jenkins A, Grizzetti B, Galloway JN, Vitousek P, Leach A, Bouwman AF, Butterbach-Bahl K, Dentener F, Stevenson D, Amann M, Voss M (2013) The global nitrogen cycle in the twenty-first century. Philos Trans Royal Soc London Series B Biol Sci 368(1621):20130164

Gary EH, Norman U (2019) Symbiotic root-endophytic soil microbes improve crop productivity and provide environmental benefits. Scientifica, PMID: 31065398

Graham WO, Nantakorn B, Dilworth MJ (1988) Mineral constraints to nitrogen fixation. Plant Soil 108(1):93-101

Hai B, Ndeye HD, Saidou S, Felix H, Kristina S, Moussa B, Komi A, Jean-Luc C, Jean CM, Michael S (2009) Quantification of key genes steering the microbial nitrogen cycle in the rhizosphere of sorghum cultivars in tropical agroecosystems. Appl Environ Microbiol 75 (15):4993-5000

Harhangi HR, Le Roy M, van Alen T, Hu BL, Groen J, Kartal B, Tringe SG, Quan ZX, Jetten MS, Op den Camp HJ (2012) Hydrazine synthase, a unique phylomarker with which to study the presence and biodiversity of anammox bacteria. Appl Environ Microbiol 78(3):752-758

Henry S, Baudoin E, Lopez-Gutierrez JC, Martin-Laurent F, Brauman A, Philippot L (2004) Quantification of denitrifying bacteria in soils by nirK gene targeted real-time PCR. J Microbiol Method 59(3):327-335

Hirotsugu F, Asami K, Norisuke U, Kengo M, Tsuneda S (2015) Selective isolation of ammoniaoxidizing bacteria from autotrophic nitrifying granules by applying cell-sorting and sub-culturing of microcolonies. Front Microbiol 6:1159, PMID: 26528282

Hofferle S, Nicol GW, Pal L, Hacin J, Prosser JI, Mandic Mulec I (2010) Ammonium supply rate influences archaeal and bacterial ammonia oxidizers in a wetland soil vertical profile. FEMS Microbiol Ecol 74(2):302-315

Holger D, Elena VL, Petra P, Ping H, Craig H, Mads A, Nico J, Marton P, Julia V, Alexandr B, Rasmus HK, Martin VB, Thomas R, Bernd B, Per HN, Michael W (2015) Complete nitrification by Nitrospira bacteria. Nature 528(7583):504-509

Hoover TR (2000) Control of nitrogen fixation genes in Klebsiella pneumoniae. In: Triplett EW (ed) Prokaryotic nitrogen fixation: a model system for the analysis of a biological process. Horizon Scientific, Summerville, pp 131-147

Howarth RW, Marino R, Cole JJ (1988) Nitrogen fixation in freshwater, estuarine, and marine ecosystem. 2. Biogeochemical controls. ASLO Assoc Sci Limnol Oceanogr 33(4(2)):688-701 
Hu HW, He JZ (2017) Comammox-a newly discovered nitrification process in the terrestrial nitrogen cycle. J Soils Sedim 17:2709-2717

Huhe Borjigin S, Wu Y, Li M, Cheng Y (2016) Microbial nitrogen cycle gene abundance in soil of cropland abandoned for different periods. PLoS One 11(5):e0154697

Inoue J, Oshima K, Suda W, Sakamoto M, Takao I, Noda S, Hongoh Y, Hattori M, Ohkuma M (2015) Distribution and evolution of nitrogen fixation genes in the phylum Bacteroidetes. Microbes Environ 30(1):44-50

Jeanette MN, Joshua PS (2011) Nitrogen mineralization- immobilization turnover. Edi 2. CRC Press, Boca Raton, pp 8-18

Jennifer ES, Kent AD, Brisson VL, Gaudin AC (2019) Agricultural management and plant selection interactively affect rhizosphere microbial community structure and nitrogen cycling. Microbiome 7(1):146, PMID: 31699148

John HH, Robert LW (1936) The pure culture isolation of ammonia oxidizing bacteria. J Bacteriol 32(6):653-670

Jung J, Yeom J, Kim J, Han J, Lim HS, Park H, Hyun S, Park W (2011) Change in gene abundance in the nitrogen biogeochemical cycle with temperature and nitrogen addition in Antarctic soils. Res Microbiol 162(10):1018-1026

Kessel MAHJ, Daan RS, Albertsen M, Nielsen PH, den Camp HJO, Boran K, Mike SMJ, Sebastian L (2015) Complete nitrification by a single microorganism. Nature 528:555-559

Kim BH, Ikeda T, Hyung SP, Kim HJ, Hyun MS, Kenji K, Kazuyoshi T, Hirosuke T (1999) Electrochemical activity of an Fe (III)-reducing bacterium, Shewanella putrefaciens IR-1, in the presence of alternative electron acceptors. Biotechnol Tech 13:475-478

Kocha H, Sebastian L, Albertsenb M, Katharina K, Craig H, Eva S, Per Halkjaer N, Michael W, Holger D (2015) Expanded metabolic versatility of ubiquitous nitrite-oxidizing bacteria from the genus Nitrospira. PNAS 112(36):11371-11376

Lampkin NH, Pearce BD, Leake AR, Creissen H, Gerrard CL, Girling R, Lloyd S, Padel S, Smith J, Smith LG, Vieweger A, Wolfe MS (2015) The role of agroecology in sustainable intensification. Organic Research Centre, Newbury

Leininger S, Urich T, Schloter M, Schwark L, Qi J, Nicol GW, Prosser JI, Schuster SC, Schleper C (2006) Archaea predominate among ammonia oxidizing prokaryotes in soil. Nature 442 (7104):806-809

Lisa YS, Martin GK (2016) The nitrogen cycle. Curr Biol 26(3):R94-R98

Lu P, Zhang JW, Jin LB, Liu W, Dong ST, Liu P (2012) Effects of nitrogen application stage on grain yield and nitrogen use efficiency of high-yield summer maize. Plant Soil Environ 58:211-216

Marcel MMK, Hannah KM, Boran K (2018) The microbial nitrogen-cycling network. Nat Rev Microbiol 16(5):263-276

Markus G, Klaubauf S, Berger H, Joseph S (2014) The functional contribution to the nitrogen cycle in agricultural soils. In: Metagenomics of the microbial nitrogen cycle: theory, methods and applications. Caister Academic Press, Norfolk, pp 209-225

Masahito H, Kanako T, Masanori S (2007) Various players in the nitrogen cycle: diversity and functions of the microorganisms involved in nitrification and denitrification. Soil Sci Plant Nutr 54(1):33-45

Moir JWB, Crossmam LC, Spiro S, Richardson DJ (1996) The purification of ammonia monooxygenase from Paracoccus denitrificans. FEBS Lett 387(1):71-74

Nadia G (2012) Role and importance of cobalt nutrition on groundnut (Arachis hypogea) production. World Appl Sci J 20(3):359-367

Nicholas OI, Babalola OO (2018) Below-ground-above-ground plant-microbial interactions: focusing on soybean, rhizobacteria and mycorrhizal fungi. Open Microbiol J 12:261-279

Norton J, Yang O (2019) Controls and adaptive management of nitrification in agriculture soils. Front Microbiol 10:1931, PMID: 31543867 
Oliver S, Russow R, Stange CF (2011) Formation of hybrid $\mathrm{N}_{2} \mathrm{O}$ and hybrid $\mathrm{N}_{2}$ due to codenitrification: first review of a barely considered process of microbially mediated N-nitrosation. Soil Biol Biochem 43(10):1995-2011

Olivia R, Schmitt J, Mike SMJ, Claudia L (2017) Metagenomic potential for and diversity of N cycle driving microorganisms in the Bothnian Sea sediment. Microbiol Open 6(4):e00475, PMID: 28544522

Pathak H (2015) Greenhouse gas emission from Indian agriculture: trends, drivers and mitigation strategies. Proc Indian Natl Sci Acad 81:1133-1149

Philippot L, Germon JC (2005) Contribution of bacteria to initial input and cycling of nitrogen in soils. In: Buscot F, Varma A (eds) Microorganisms in soils: roles in genesis and functions, vol 3. Springer, Berlin, pp 159-176

Poly F, Monrozier LJ, Bally R (2001) Improvement in the RFLP procedure for studying the diversity of nifH genes in communities of nitrogen fixers in soil. Res Microbiol 152:95-103

Ramiro R, Silvia P (2018) Reviews and syntheses: processes and functional genes involved in nitrogen cycling in marine environments. Biogeosciences:279

Ranitha M, Mansor N, Beshr A-K, Helmi Mohamad M, Rashid MS (2017) Evaluation of allicin as soil urease inhibitor. Advances in material processing technologies conference. Procedia Eng 184:449-459

Raven JL, Barkhem RM (1974) Experience with a commercial kit for the radioisotopic assay of vitamin $\mathrm{B}_{12}$ in serum: the Phadebas $\mathrm{B}_{12}$ test. J Clin Pathol 27:59-65

Risgaard-Petersen N, Alexandra ML, Signe I, Markus CS, Mike SMJ, Huub JM, Camp O, Derksen JMW, Piña-Ochoa E, Susanne PE, Nielsen LP, Niels PR, Tomas C, Gijsbert JZ (2006) Evidence for complete denitrification in a benthic foraminifer. Nature 7(443(7107)):93-96

Robertson GP, Vitousek PM (2009) Nitrogen in agriculture: balancing the cost of an essential resources. Ann Rev Environ Resour 34:97-125

Rockstrom J, Steffen W, Noone K, Persson A, Chapin FS, Lambin EF, Lenton TM, Scheffer M, Folke C, Schellnhuber JJ, Nykvist B, de Wit CA, Hughes T, van der Leeuw S, Rodhe H, Sorlin S, Snyder PK, Costanza R, Svedin U, Falkenmark M, Karlberg L, Corell RW, Fabry VJ, Hansen J, Walker B, Liverman D, Richardson K, Crutzen P, Foley JA (2009) A safe operating space for humanity. Nature 461(7263):472-475

Romain D, Zhang X, McRose DL, Jolanta M, Francois L, Anne MLK, Jean-Philippe B (2017) Biological nitrogen fixation by alternative nitrogenases in boreal cyanolichens: importance of molybdenum availability and implications for current biological nitrogen fixation estimates. New Phytol 213:680-689

Rosch C, Mergel A, Bothe H (2002) Biodiversity of denitrifying and dinitrogen-fixing bacteria in an acid forest soil. Appl Environ Microbiol 68:3818-3829

Shilpha SM, Soumya TM, Girijesh GK, Dhananjaya BC (2017) Effect of different natural oil coated urea fertilizers on productivity and nutrient uptake of maize. Int J Pure Appl Biosci 5 (2):807-812

Shinn MB (1941) Colorimetric method for determination of nitrate. Ind Eng Chem Anal Ed 13 (1):33-35

Shoun H, Fushinobu S, Jang L, Sang-Wan K, Takayoshi W (2012) Fungal denitrification and nitric oxide reductase cytochrome P450nor. Philos Trans Royal Soc London Biol Sci 367 (1593):1186-1194

Siddarame Gowda TK, Rajaramamohan V, Sethunathan N (1977) Heterotrophic nitrification in the simulated oxidized zone of a flooded soil amended with benomyl. Soil Sci 123(3):171-175

Silvia P, Brendan JMB (2016) Ecology of nitrogen fixing, nitrifying and denitrifying microorganisms in tropical forest soils. Front Microbiol 7:01045, PMID: 27468277

Strous M, Kuenen JG, Jetten MS (1999) Key physiology of anaerobic ammonium oxidation. Appl Environ Microbiol 65(7):3248-3250

Subbarao GV, Nakahara K, Ishikawa T, Ono H, Yoshida M, Yoshihashi T, Zhu Y, Zakir HAKM, Deshpande SP, Hash CT, Sahrawat KL (2013) Biological nitrification inhibition (BNI) activity in sorghum and its characterization. Plant Soil 366:243-259 
Subbaraoa GV, Tadashi Y, Margaret W, Kazuhiko N, Yasuo A, Kanwar LS, Madhusudhana RI, Jean-Christophe L, Masahiro K, Hans-Joachim B (2015) Suppression of soil nitrification by plants. Plant Sci 233:155-164

Tanimoto T, Hatano K, Kim D, Hiroo U, Hirofumi S (1992) Co-denitrification by the denitrifying system of the fungus Fusarium oxysporum. FEMS Microbiol Lett 93(2):177-180

Terence RW, Michael AC (2003) Isolation and identification of hyper-ammonia producing bacteria from swine manure storage pits. Curr Microbiol 48:20-26

Vitousek PM (1999) Nutrient limitation to nitrogen fixation in young volcanic sites. Ecosystems 2 (6):505-510

Wang Q, Quensen JF III, Fish JA, Lee TK, Sun Y, Tiedje JM, Cole JR (2013) Ecological patterns of nifH genes in four terrestrial climatic zones explored with targeted metagenomics using Frame Bot, a new informatics tool. MBio 4(5):e00592-13, PMID: 24045641

Wang H, Xu L, Li X, Li X, Wang J, Zhang H (2017) Changes of microbial population and N cycling function genes with depth in three Chinese paddy soils. PLoS One 12(2):e0189506, PMID: 29284018

Wang L, Cheng X, Pan X, Chen F, Yi L (2018) Application of controlled-release urea enhances grain yield and nitrogen use efficiency in irrigated rice in Yangtze River basin, China. Front Plant Sci 9:999, PMID: 30073007

Weria W, Yaghoub R, Kaveh HA (2013) Role of some mineral nutrients in biological nitrogen fixation. Bull Environ Pharmacol Life Sci 2(4):77-84

Wu D, Wenxu D, Oenema O, Yuying W, Ivonne T, Chunsheng H (2013) $\mathrm{N}_{2} \mathrm{O}$ consumption by low-nitrogen soil and its regulation by water and oxygen. Soil Biol Biochem 60:165-172

Yan Y, Pan J, Zhou Z, Wu J, Yang L, Lin J, Hong Y, Li X, Li M, Gu J (2020) Complex microbial nitrogen-cycling networks in three distinct anammox-inoculated wastewater treatment systems. Water Res 168:31605831, PMID: 31605831

Yaying L, Stephen JC, Graeme WN, Huaiying Y (2018) Nitrification and nitrifiers in acidic soils. Soil Biol Biochem 116:2901-2301

Yuntao H, Zheng Q, Shasha Z, Lisa N, Wolfgang W (2018) Significant release and microbial utilization of amino sugars and D-amino acid enantiomers from microbial cell wall decomposition in soils. Soil Biol Biochem 123:115-125

Zehr JP, Bethany DJ, Stevens MS, Grieg FS (2003) Nitrogenase gene diversity and microbial community structure: a cross-system comparison. Environ Microbiol 5(7):539-554

Zhang X, Liu W, Schloter M, Zhang G, Chen Q, Huang J, Linghao L, James JE, Han X (2013) Response of the abundance of key soil microbial nitrogen-cycling genes to multi-factorial global changes. PLoS One 8(10):e76500, PMID: 24124568

Zhang J, Muller C, Zucong C (2015) Heterotrophic nitrification of organic N and its contribution to nitrous oxide emissions in soils. Soil Biol Biochem 84:199-209

Zhou Y, Qin Y, Liu X, Feng Z, Zhu H, Yao Q (2019) Soil bacterial function associated with Stylo (legume) and Bahiagrass (grass) is affected more strongly by soil chemical property than by bacterial community composition. Front Microbiol 10:798, PMID: 31031740

Zhu T, Yang C, Wang J, Zeng S, Liu M, Yang J (2018) Bacterivore nematodes stimulate soil gross $\mathrm{N}$ transformation rates depending on their species. Biol Fertility Soil 54:107-118 